\title{
PREVALENCE OF CLAW DISEASES IN DAIRY COWS WITH DIFFERENT BODY CONDITION
}

\author{
Mudroň, P., Höskuldsson, T., Mihajlovičová, X. \\ Clinic for Ruminants \\ University of Veterinary Medicine and Pharmacy, Komenského 73, 04181 Košice \\ Slovakia \\ pavol.mudron@uvlf.sk
}

\section{ABSTRACT}

The aim of this study was to examine the relationship between body condition and claw diseases in dairy cows. The data used in this study were obtained during two sessions of routine orthopaedic treatment and hoof trimming on a dairy farm in Eastern Slovakia. In the spring and autumn terms, 482 dairy cows were examined for claw diseases and their body conditions were recorded. Out of the 482 dairy cows, $56 \%$ were affected by one or more claw diseases in one or more legs. Digital dermatitis and sole ulcers were the most often detected claw diseases found in this study. The dairy cows with a low body condition score $(\mathrm{BCS}<3)$ showed a higher prevalence of claw diseases $(\mathrm{P}<0.05)$ than the cows with a body condition score greater than 3 . However, this difference could not be found when infectious diseases of the claws (digital dermatitis, foot rot, and interdigital dermatitis) were analysed. The results of this study allowed us to conclude that the dairy cows with a lower grade of body condition suffered more from non-infectious claw diseases (sole ulcer, white line diseases).
Key words: body condition score; claw diseases; dairy cows; lameness

\section{INTRODUCTION}

In the recent decades, animal welfare has been receiving more and more attention in Europe as well as in other parts of the world. Lameness is one of the most important welfare issues occurring in the intensive dairy industry, and is also a source of substantial economic losses in the dairy industry [16]. Lameness is also considered one of the greatest sources of economic loss in the intensive dairy industry, in Western Europe and North America, second only to infertility and mastitis. While in the developing countries lameness is less important than infectious diseases and malnutrition [3]. The diseases of the claws account for up to $90 \%$ of all bovine lameness cases [8].

When evaluating the cost of each case of lameness, many factors have to be considered, which can be divided into direct and indirect costs. Indirect losses are related to: 
prolonged calving interval, culling losses, reduced milk yield, weight loss and replacement costs. The direct losses are considered to be the veterinary expenses and drugs. A quarter of all losses of lameness, are due to the reduced milk yield and the discarded antibiotic-treated milk during the therapy periods. Cows with a higher yield have an increased risk of lameness, and problems with lameness occur primarily in the early lactation period; one to three months postpartum. The fertility problems caused by lameness are the result of:

1. Failure of oestrus detection, because the cows are often unwilling/unable to mount other cows;

2. Anoestrus;

3. Poor body condition at the time of insemination and negative energy balance; and

4. Low grade metritis [15].

In the recent years, more focus has been directed into what role the body condition of cows and lipid mobilisation plays in the development of claw diseases. Research has indicated that body condition scores correlate positively with the thickness of the digital cushion, and that the digital cushion thickness correlates negatively with claw capsule lesions [1].

A fundamental part of controlling bovine claw diseases, as with any other disease, is a comprehensive understanding of the aetiology, risk factors, and pathophysiology of the development of the diseases. The purpose of this study was to examine the relationship between body condition score and claw diseases in dairy cows in order to form a better understanding of the development of claw diseases.

\section{MATERIALS AND METHODS}

The data used in this study were obtained during two sessions of routine orthopaedic and claw trimming visits (spring and autumn) to a dairy farm in Eastern Slovakia. In total, 482 dairy cows were included in the study. The cows at the farm were regularly trimmed twice a year and all of them were trimmed and examined at each of the two sessions from which the data were obtained. All of the cows were pure Holstein Friesian breed that were kept on manure solid bedding and fed a total mixed rations (TMR).

The Body condition score (BCS) and the following claw diseases were recorded during the examination: digital dermatitis, interdigital hyperplasia, sole ulcer, toe ulcer, acute/ chronic/sub-clinical laminitis, foot rot, double sole, and white line disease [6].

The body condition of the cows was scored on a scale of $1-5$ in 0.25 increments [5]. It was based on the examination of the transverse processes of the lumbar vertebrae, the ribs, ischial tuberosity, ligaments of the pelvis and surrounding fat.

The difference in the occurrence of claw diseases in groups with different BCS ( 3 groups: $<3 ; 3-4$; >4) was evaluated by the Chi-Square test for all main non-infectious (sole ulcer and white line diseases), and infectious diseases (digital dermatitis, interdigital dermatitis, and foot rot).

\section{RESULTS}

Out of the 482 dairy cows examined during spring and autumn terms, 270 (56\%) were affected by one or more claw diseases in one or more legs. The diseases were most predominately seen in the hind legs. The most commonly diagnosed diseases were digital dermatitis (36\%) and sole ulcers (13\%). Only one case of interdigital dermatitis was recorded and no cases of acute laminitis or foot rot were diagnosed.

The group of cows with BCS below 3 had a considerably higher prevalence $(\mathrm{P}<0.05)$ of cows affected by claw diseases $(66 \%)$. The highest difference $(\mathrm{P}<0.01)$ in the prevalence of claw diseases within the BCS groups could be

Table 1. Prevalence of claw diseases in cows with different BCS

\begin{tabular}{lcccc}
\hline \multicolumn{1}{c}{ Variable } & BCS $<3$ & BCS 3-4 & BCS $>\mathbf{4}$ & $\mathbf{X}^{2}$ test \\
\hline Number of dairy cows & $\begin{array}{c}125 \\
(100 \%)\end{array}$ & $\begin{array}{c}314 \\
(100 \%)\end{array}$ & $\begin{array}{c}43 \\
(100 \%)\end{array}$ & \\
& 83 & 165 & 22 & \\
All claw diseases & $(66 \%)^{\mathrm{a}}$ & $(53 \%)^{\mathrm{b}}$ & $(51 \%)^{\mathrm{b}}$ & $\mathrm{P}<0.05$ \\
& 28 & 37 & 1 & \\
$\begin{array}{l}\text { Non-infectious } \\
\text { claw diseases }\end{array}$ & $(22 \%)^{\mathrm{a}}$ & $(12 \%)^{\mathrm{b}}$ & $(2 \%)^{\mathrm{c}}$ & $\mathrm{P}<0.01$ \\
& 51 & 112 & 15( & \\
Infectious claw diseases & $(41 \%)$ & $(36 \%)$ & $35 \%)$ & \\
& 4 & 16 & 6 & \\
Other claw diseases & $(3 \%)$ & $(5 \%)$ & $(14 \%)$ & \\
& & & &
\end{tabular}

$a, b, c$ - values with the different superscripts differ at $P<0.05$; Non-infectious claw diseases: sole ulcer and white line diseases; Infectious claw diseases: digital dermatitis, interdigital dermatitis, and foot rot 
seen for sole ulcer and white line disease (WLD) with the highest prevalence in the lowest BCS group. In contrast, no significant difference could be found in the prevalence of the infectious claw diseases (Table 1).

\section{DISCUSSION AND CONCLUSIONS}

Sole ulcers were a lot more frequent and were the second most commonly diagnosed disease in this study after digital dermatitis. Sole ulcers are one of the most common causes of lameness in dairy cows and the most important one [14]. Over the last few years, an extensive change has been in the supposed role of nutritional management in the control of lameness. In the past, the control of subacute ruminal acidosis (SARA) was believed to be a major factor in limiting claw horn lesions because of SARA's suggested role in the development of laminitis [4]. The control of SARA is still believed to be important for maintaining the health and production but it has now been proven to be of low priority in the control of lameness. If the results of recent studies prove to be correct, more focus should be put into minimizing condition loss during early lactation. Cows with low BCS in the periparturient period and early lactation were 3 to 9 times more likely to suffer from lameness than cows with higher BCS [7]. The prevalence of sole ulcers has been significantly associated with digital cushion thickness and BCS is positively correlated with the digital cushion thickness [1]. During early lactation, adipose tissue is mobilized and partitioned toward the mammary gland to support milk production [11]. Research suggests that adipose tissue is not only being mobilized from other parts of the body, such as intra-abdominal fat, subcutaneous fat, and muscle, but also from the digital cushion [1]. Moreover, older cows tend to have lower BCS, lower digital cushion thickness and increased levels of hoof damage [10]. Recently, the association between sole soft tissue thickness and claw lesion incidence was investigated in dairy cows. It could be found that cows which developed sole ulcers had a thinner digital cushion before the lesion occurrence [9]. However, they did not demonstrate a direct link between the decrease in the thickness of back fat and digital cushion after calving. This could possibly be due to a different rate of fat mobilization in the back area and in the claw. A thin digital cushion is believed to have a decreased ability to dampen compression of the corium by the third phalanx. Therefore, a reduction of the number of cows with low BCS at calving and decreasing condition loss in early lactation should most likely be a part of controlling claw horn lesions. The results of this study support these theories.

There was a significant difference in the prevalence of sole ulcers between the three groups of BCS. Only $2 \%$ of the cows with BCS over 4 suffered from this disease, while $22 \%$ of the cows with BCS lower than 3 were affected. As mentioned before, due to the limitation of the data used in this study, it is not possible to know for sure if cows with poor condition are more likely to develop white line disease and sole ulcer, or if cows with these diseases lose their condition as a consequence. To be able to differentiate between cause and effect the cows would have to be examined for these diseases and BCS evaluated on, for example, a weekly or monthly basis. However, some studies have demonstrated no dramatic drop in milk production in cows suffering from light grades of lameness [13]. Therefore, no significant increase in energy need should be expected in no severe forms of sole ulcer.

Digital dermatitis (DD) is an infectious disease and the most commonly found microbe is the bacteria Treponema spp. [2]. This infectious disease of cattle claws belongs to the most frequent causes of bovina lameness. Recently, a prevalence of $40 \%$ for digital dermatitis was reported from dairy herds [12] which was similar to the observation in the present study. Known risk factors for cows to develop DD are increased amounts of moisture, urine and faeces in the pathways where the cows walk. A low BCS is not a known risk factor for digital dermatitis and there was no significant difference between the three BCS groups.

In conclusion, the results of this study indicated that there was an association between body condition score and the prevalence of non-infectious claw diseases. The cows with low body condition score are at risk of a higher prevalence of non-infectious claw diseases.

\section{ACKNOWLEDGEMENT}

This study was supported by the Slovak Research and Development Agency under the contract No. APVV-0701-11. 


\section{REFERENCES}

1. Bicalho, R.C., Machado, V.S., Caixeta, A. L.S., 2009: Lameness in dairy cattle: A debilitating disease or a disease of debilitated cattle? A cross-sectional study of lameness prevalence and thickness of the digital cushion. J. Dairy Sci., 92, 3175-3184.

2. Capion, N., Boye, M., Ekstrom, C., Dupont, K., Jensen, T., 2013: A study into digital dermatitis transmission and bacterial associated pathological changes involved in the disease. Open Journal of Veterinary Medicine, 3, 192-198.

3. Collick, D. W., Ward, W.R., Dobson, H., 1989: Associations between types of lameness and fertility. Vet. Rec., 125, 103-106.

4. Danscher, A.M., Toelboell, T.H., Wattle, O., 2010: Biomechanics and histology of bovine claw suspensory tissue in early acute laminitis. J. Dairy Sci., 93, 53-62.

5. Edmonson, A. J., Lean, I. J., Weaver, L. D., Farver, T., Webster, G., 1989: A body condition scoring chart for Holstein cows. J. Dairy Sci., 72, 68-78.

6. Egger-Danner, C., Nielsen, P., Fiedler, A., Müller, K., Fjeldaas, T., Döpfer, D., et al., 2015: ICAR Claw Health Atlas. Rome, ICAR, 45 pp. http://www.icar.org/Documents/ ICAR_ Claw_Health_Atlas.pdf.

7. Hoedemaker, M., Prange, D., Gundelach, Y., 2009: Body condition change ante- and postpartum, health and reproductive performance in German Holstein Cows. Reprod. Domestic Anim., 44, 167-173.

8. Murray, R.D., Downham, D.Y., Clarkson, M.J., Faull, W. B., Hughes, J. W., Manson, F. J., et al., 1996: Epidemiology of lameness in dairy cattle: description and analysis of foot lesions. Vet. Rec., 138, 586-591.
9. Newsome, R. F., Green, M. J., Bell, N. J., Bollard, N. J., Mason, C.S., Whay, H.R., Huxley, J.N., 2017: A prospective cohort study of digital cushion and corium thickness. Part 1: Associations with body condition, lesion incidence, and proximity to calving. J. Dairy Sci., 100, 4745-4758.

10. Räber, M., Scheeder, M.R.L., Ossent, P., Lischer, Ch. J., Geyer, H., 2006: The content and composition of lipids in the digital cushion of the bovine claw with respect to age and location - A preliminary report. Vet. J., 172, 173-177.

11. Rastani, R. R., Andrew, S.M., Zinn, S., Sniffen, C. J., 2001: Body composition and estimated tissue energy balance in Jersey and Holstein cows during early lactation. J. Dairy Sci., 84, 1201-1209.

12. Solano, L., Barkema, H. W., Pickel, C., Orsel, K., 2017: Effectiveness of a standardized footbath protocol for prevention of digital dermatitis. J. Dairy Sci., 100, 1295-1307.

13. Solano, L., Barkema, H. W., Pajor, E. A., Mason, S., Leblanc, S. J., Nash, C. G., et al., 2016: Associations between lying behaviour and lameness in Canadian Holstein-Friesian cows housed in freestall barns. J. Dairy Sci., 99, 2086-2101.

14. Van Amstel, S.R., Shearer, J. K., 2006: Review of Pododermatitis circumscripta (ulceration of the sole) in dairy cows. J. Vet. Internal. Med., 20, 805-811.

15. Weaver, A.D., Guy S. J., Steiner, A., 2007: Bovine Surgery and Lameness. 2nd edn., Wiley-Blackwell Publishing Ltd., Oxford, $290 \mathrm{pp}$.

16. Whay, H.R, Main, D.C.J., Webster, A.J.F., Green, L.E., 2003: Assessment of the welfare of dairy cattle using animalbased measurements: direct observations and investigation of farm records. Vet. Rec., 153, 197-202.

Received June 13, 2017

Accepted July 6, 2017 